\title{
Suppression of Amphibian Metamorphosis by Bisphenol A and Related Chemical Substances
}

\author{
Yasushi Goto, ${ }^{a}$ Shigeyuki Kitamura, ${ }^{*}, b$ Keiko Kashiwagi, ${ }^{a}{ }^{\text {Ken Oofusa, }}{ }^{c}$ Osamu Tooi, ${ }^{d}$ \\ Katsutoshi Yoshizato, ${ }^{e}$ Jin Sato, ${ }^{a}$ Shigeru Ohta, ${ }^{b}$ and Akihiko Kashiwagi ${ }^{a}$
}

anstitute for Amphibian Biology, Graduate School of Science, Hiroshima University, 1-3-1 Kagamiyama, Higashihiroshima 7398526, Japan, ${ }^{b}$ Graduate School of Biomedical Sciences, Hiroshima University, Kasumi 1-2-3, Minami-ku, Hiroshima 734-8551, Japan, 'ProPhoenix Company Limited, Hiroshima Techno Plaza, 3-13-26 Kagamiyama, Higashihiroshima 739-0046, Japan, ${ }^{d}$ Biotechnology Research Laboratory, Towa Kagaku Co., Ltd., 3-13-26 Kagamiyama, Higashihiroshima 739-0046, Japan, and ${ }^{e}$ Laboratory of Developmental Biology, Department of Biological Science, Graduate School of Science, Hiroshima University, 1-3-1 Kagamiyama, Hiashihiroshima 739-8526, Japan

(Received January 5, 2006; Accepted January 12, 2006; Published online January 23, 2006)

\begin{abstract}
This investigation attempts to clarify the effects of the plastic monomer bisphenol A (BPA) and related chemicals on 3,3',5-triiodothyronine $\left(\mathrm{T}_{3}\right)$-induced and spontaneous anuran tadpole tail regression. $\mathrm{T}_{3}$-induced tail regression was found to be suppressed by BPA and tetrabromobisphenol A (TBBPA), tetrachlorobisphenol A (TCBPA), and tetramethylbisphenol A (TMBPA). $\mathrm{T}_{3}$-treated Rana rugosa tadpole tails displayed marked apoptotic features, including DNA fragmentation and ladder-like profiles, as opposed to essentially little or no fragmentation and ladder formation for BPA, TBBPA, TCBPA and TMBPA-treated tails. BPA and related compounds also inhibited Silurana tropicalis spontaneous metamorphosis controlled by endogenous circulating thyroid hormone (TH). These results indicate that BPA and related compounds are TH antagonists. In transgenic Xenopus laevis tadpoles carrying plasmid DNA containing TH response element (TRE) and $5^{\prime}$-upstream promoter region of the TH receptor (TR) $\beta$ A1 gene linked to a green fluorescent protein (EGFP) gene, $\mathrm{T}_{3}$ induced a strong EGFP expression in the hind limbs, while $\mathrm{T}_{3}$ plus BPA, TBBPA, TCBPA or TMBPA suppressed the expression, suggesting BPA and related chemicals all act in preventing the binding of $\mathrm{T}_{3}$ to $\mathrm{TR}$, resulting in inhibition of TR-mediated gene expression.
\end{abstract}

Key words — amphibian metamorphosis, apoptosis, bisphenol A related compound, endocrine disruptor, thyroid hormone antagonist, transgenic frog

\section{INTRODUCTION}

Endocrine disruptors include a group of chemicals which disturb normal endocrine activity, and are a suspected cause in the depletion of wildlife populations and various human health problems. ${ }^{1-4)}$ Bisphenol A (BPA) - an industrial raw material for polycarbonate and epoxy resins - is one of the most common endocrine disruptors. BPA has been found to antagonize thyroid hormone (TH) action in vitro and in vivo assays. ${ }^{5,6)}$ The brominated BPA analogue, tetrabromobisphenol A (TBBPA), is widely used as a flame retardant in building materials, paints, etc., ${ }^{7)}$ and has been reported to be weakly estrogenic in

*To whom correspondence should be addressed: Graduate School of Biomedical Sciences, Hiroshima University, Kasumi 1-2-3, Minami-ku, Hiroshima 734-8551, Japan. Tel.: +81-82257-5328; Fax: +81-82-257-5329; E-mail: skitamu@hiroshimau.ac.jp vitro, ${ }^{8-10)}$ to bind thyroid hormone receptor (TR) in vitro, ${ }^{11,12)}$ and to antagonize the biological function of TH in vivo. ${ }^{12)}$ TBBPA inhibits larval development in Xenopus laevis (X. laevis). ${ }^{13)}$ The chlorinated structural analogue, tetrachlorobisphenol A (TCBPA), is found in the effluent from waste-paper recycling plants. ${ }^{14)}$ The methylated structural analogue, tetramethylbisphenol A (TMBPA), is used in polycarbonate resin. Both TCBPA and TMBPA have been found to bind the TR. ${ }^{11,12)}$

TH is important in various physiological processes in animal metabolism, development and growth. Amphibian tadpole metamorphosis is a THcontrolled developmental process. ${ }^{15-19)} \mathrm{TR}$ forms a heterodimer with a retinoid X receptor (RXR), thereby binding to the thyroid hormone response element (TRE) in the target genes. This is followed by binding to 3,3',5-triiodothyronine $\left(\mathrm{T}_{3}\right)$ to enhance or repress gene transcription. ${ }^{18)} 3,3^{\prime}, 5,5^{\prime}$-tetraiodothyronine $\left(\mathrm{T}_{4}\right)$ regulates the expression of a va- 
riety of genes. ${ }^{20)}$ Of the genes which are regulated by THs in the tail shortening program of X. laevis, 17 genes have been observed to be up-regulated and 4 genes down-regulated. ${ }^{16)}$ Tadpole tail regression during anuran metamorphosis is the result of muscle cell apoptosis, or programmed cell death, ${ }^{19,21,22)}$ and is triggered and controlled by THs. Apoptosis hallmarks include chromatin condensation, protease and endonuclease activation, internucleosomal DNA fragmentation, ladder formation, membrane blebbing and cell shrinkage. ${ }^{23)}$ Little information is available regarding the effects of BPA and related compounds on the amphibian thyroid system and metamorphosis. The addition of the THs $\mathrm{T}_{3}$ and $\mathrm{T}_{4}$ to the culture medium (water) of premetamorphic stage tadpoles results in an enhancement of the metamorphic process, ${ }^{24-26)}$ and this $\mathrm{TH}$-induced enhancement has proven to be a useful tool for investigating the effects of various substances [for example $N$-monomethylL-arginine (NMMA), $N$-tosyl-L-phenylalanyl chloromethyl ketone (TPCK), cyclosporin A] on the thyroid system and amphibian growth and development. ${ }^{22,27)}$ In the present investigation, we use THinduced enhancement to examine the disruptive effects of BPA, TBBPA, TCBPA and TMBPA on $\mathrm{T}_{3}$ activity (Fig. 1) and tail cell apoptosis in three amphibian species. We also examine their effect on TRmediated gene expression.

\section{MATERIALS AND METHODS}

Chemicals — BPA, TBBPA, TCBPA and TMBPA were purchased from Tokyo Chemical Industry Co. Ltd. (Tokyo, Japan). $\mathrm{T}_{3}$ and dimethyl sulfoxide (DMSO) were obtained from Wako Pure Chemical Industries Ltd. (Osaka, Japan). Methimazole was obtained from Sigma-Aldrich, Inc. (St. Louis, MO, U.S.A.). Test compounds were solubilized in DMSO, and assays were conducted in $0.1 \%$ DMSO solution.

Animal Maintenance —— Three amphibian species, Rana rugosa (R. rugosa), Silurana tropicalis (S. tropicalis) and X. laevis were used in the present investigation.

Adult specimens of $R$. rugosa were raised in the laboratory. Ovulation was induced by injecting Rana catesbeiana (bullfrog) pituitaries into the body cavity of mature females. Eggs from a single female were artificially fertilized with a chlorine-free water suspension of crushing male testes. Tadpoles were
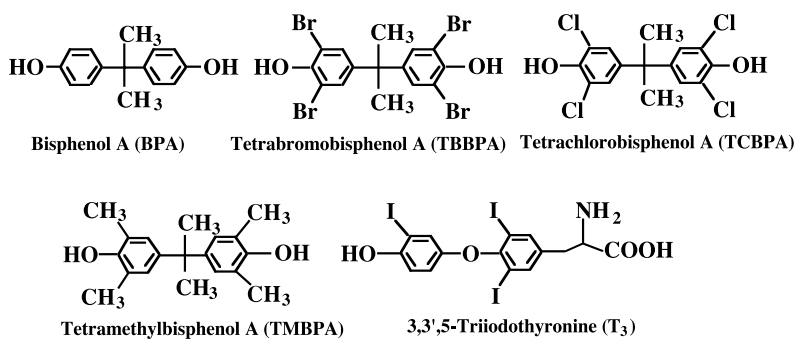

Fig. 1. Structures of BPA, TBBPA, TCBPA, TMBPA and $T_{3}$

fed on boiled spinach and staged according to the criteria of Taylor and Kollros. ${ }^{28)}$

S. tropicalis used in the present study were maintained in the Institute for Amphibian Biology, Graduate School of Science, Hiroshima University as part of a national bioresource project conducted by the Ministry of Education, Culture, Sports, Science and Technology, while adult $X$. laevis were derived from standard strains maintained by the Hiroshima University Institute for Amphibian Biology. Mating for both species was induced by injecting human chorionic gonadotropin (hCG; Sigma) into the dorsal lymph sac (S. tropicalis males - $125 \mathrm{U}$, females $300 \mathrm{U}$; X. laevis males - $125 \mathrm{U}$, females - 500$600 \mathrm{U})$. Matings for S. tropicalis were carried out by placing one male-female pair into a tank with 5$10 \mathrm{~cm}$ of chlorine free tap water at $23^{\circ} \mathrm{C}$ for $4-5 \mathrm{hr}$, and matings for $\mathrm{X}$. laevis were carried out at $19^{\circ} \mathrm{C}$ for 10-12 hr. Tadpoles of both species were raised with SERA Micron (Sera Heinsberg, Germany) and staged according to Nieuwkoop and Faber. ${ }^{29)}$

Extraction of DNA and Analysis of Fragmentation and Laddering — DNA was extracted from the tail using phenol/chloroform $(1: 1)$ as described previously. ${ }^{30,31)}$ Tails were homogenized in a lysis buffer (50 mM Tris-HCl, pH 7.8, 10 mM EDTA, $0.5 \%$ sodium- $N$-lauroylsarcosinate). Fragmentation of DNA was quantified by the diphenylamine method. ${ }^{30)}$ Briefly, the lysate was centrifuged at $13000 \times g$ at $4^{\circ} \mathrm{C}$ for $20 \mathrm{~min}$ to separate intact and fragmented chromatin. Each fraction was treated with $0.2 \mathrm{ml}$ of $6 \%$ perchloric acid (PCA) for $30 \mathrm{~min}$ and then centrifuged at $13000 \times g$ for $20 \mathrm{~min}$ at $4{ }^{\circ} \mathrm{C}$. Precipitated fractions were treated with $50 \mu \mathrm{l}$ of $6 \%$ PCA at $70^{\circ} \mathrm{C}$ for $20 \mathrm{~min} .0 .1 \mathrm{ml}$ of diphenylamine solution (1.5\% diphenylamine, $1.5 \%$ sulfuric acid, $0.01 \%$ acetaldehyde in acetic acid) was added to the samples and these were allowed to stand overnight at $30^{\circ} \mathrm{C}$. The samples were then determined spectrophotometrically at $600 \mathrm{~nm}$, and the percentage of 
fragmented DNA was calculated from the amount of DNA found in the supernatant.

Ladder-like profiles of electrophoresed DNA samples were analyzed as described previously. ${ }^{31}$ Briefly, homogenates were incubated with $1 \mathrm{mg} / \mathrm{ml}$ of proteinase $\mathrm{K}$ for $30 \mathrm{~min}$ and subsequently with $1 \mathrm{mg} / \mathrm{ml}$ of RNase for $30 \mathrm{~min}$ at $50^{\circ} \mathrm{C}$. The DNA samples thus obtained (1.5 from $5 \mu \mathrm{g}$ of total DNA) were subjected to $2 \%$ agarose gel electrophoresis at $100 \mathrm{~V}$ using a running buffer containing $90 \mathrm{mM}$ Tris- $\mathrm{HCl}$ ( $\mathrm{pH} 8.0$ ), $90 \mathrm{mM}$ boric acid and $2 \mathrm{mM}$ EDTA. After electrophoresis, gels were stained with $0.1 \mu \mathrm{g} / \mathrm{ml}$ ethidium bromide and observed under ultraviolet light. ${ }^{32)}$

Assay of Enhanced Green Fluorescent Protein (EGFP) Activity — Transgenic X. laevis were produced using the transgenesis procedure described in Kroll and Amaya, ${ }^{33)}$ by which plasmid DNA containing $5^{\prime}$-upstream promoter region plus TRE of the TR $\beta A 1$ gene linked to EGFP gene is integrated into the chromosomes of isolated sperm nuclei in vitro, followed by transplantation of the nuclei into unfertilized eggs to begin development, producing transgenic tadpoles and frogs $\left(\mathrm{F}_{0}\right) \cdot{ }^{34)}$ In the resulting transgenic embryos and tadpoles, a weak EGFP expression was first observed at the neurula stage, and a strong expression was observed at metamorphic climax. In the present study, mature first generation offspring $\left(\mathrm{F}_{1}\right)$ males were mated with normal females. All transgenic males produced offspring (second generation offspring, $\mathrm{F}_{2}$ ) in large numbers, and $\mathrm{T}_{3}$-treated offspring showed stable EGFP expression ubiquitously throughout the whole body, particularly strongly in the hind limbs.

EGFP expression in tadpoles was monitored using a fluorescent dissecting microscope (MZ FLIII, Leica) equipped with a digital camera (D70, Nikon, Tokyo, Japan). Quantitative analysis of EGFP expression was performed using Corel PHOTO-PAINT 11 (Corel Corporation, Ontario, Canada).

Statistical Analyses — DNA fragmentation was analyzed using the Chi-square test. Unless otherwise stated, results are expressed as the mean \pm SEM. Statistical differences between untreated control and BPA and related compounds or $\mathrm{T}_{3}$-treated groups were analyzed using Student's $t$-test and Welch's $t$ test. $p$-Values below 0.05 are considered significant.

\section{RESULTS}

\section{Effect of BPA and Related Compounds on Tad- pole Tail Shortening in $T_{3}$-Induced Metamorpho- sis}

Figure 2 shows the effect of BPA, TBBPA, TCBPA and TMBPA on tail shortening in $\mathrm{T}_{3}$-treated and untreated tadpoles. Stage X R. rugosa tadpoles were raised at a population density of one individual per $50 \mathrm{ml}$ in trays containing various solutions as follows: Group-1 tadpoles in $\mathrm{Cl}$-free tap water, group-2 and -3 tadpoles in tap water containing $10^{-6}$ to $10^{-8} \mathrm{M}$ of BPA, group- 4 and -5 tadpoles were raised in tap water containing $10^{-6}$ to $10^{-8} \mathrm{M}$ TBBPA, group- 6 and -7 tadpoles were raised in tap water containing $10^{-6}$ to $10^{-8} \mathrm{M}$ TCBPA, and group- 8 and -9 tadpoles were raised in tap water containing $10^{-6}$ to $10^{-8} \mathrm{M}$ TMBPA. After 5 days, $5 \times 10^{-8} \mathrm{M}$ of $\mathrm{T}_{3}$ was added to the water of groups $1,3,5,7$ and 9, and treatment was continued for one day. At the end of $\mathrm{T}_{3}$ treatment, group-1 tadpoles were returned to water only, group-3 tadpoles to the BPA solution, group-5 tadpoles to the TBBPA solution, group-7 tadpoles to the TCBPA solution, and group-9 tadpoles to the TMBPA solution, and these groups were further maintained for another 3 days. Groups 2, 4 , 6 , and 8 continued treatment for all 9 days with no addition of $\mathrm{T}_{3}$. Control tadpoles were raised in water and not exposed to BPA, TBBPA, TCBPA, TMBPA or $\mathrm{T}_{3}$. The results show that $\mathrm{T}_{3}$ induces tail shortening, and that this is suppressed by BPA $\left(10^{-6}\right.$ and $\left.10^{-7} \mathrm{M}\right)$, TBBPA $\left(10^{-6}\right.$ and $\left.10^{-7} \mathrm{M}\right)$, TCBPA $\left(10^{-6}\right.$ to $\left.10^{-8} \mathrm{M}\right)$ and TMBPA $\left(10^{-6}\right.$ and $\left.10^{-7} \mathrm{M}\right)$ in a dosedependent manner.

\section{Effects of BPA and Related Compounds on $\mathrm{T}_{3^{-}}$ Induced Tail Apoptosis}

Figure 3 shows the effect of BPA, TBBPA, TCBPA and TMBPA on DNA fragmentation and ladder formation in tails of $\mathrm{T}_{3}$-treated and untreated $R$. rugosa tadpoles. Experimental conditions were the same as described above. DNA fragmentation and ladder formation were carried out on the third day after completion of $T_{3}$ treatment. DNA in tails of $\mathrm{T}_{3}$-treated group- 1 tadpoles showed marked fragmentation (Fig. 3A and 3C) and a ladder-like profile (Fig. 3B and 3D). These changes were not observed in group- $3\left(\mathrm{~T}_{3}+10^{-6} \mathrm{M} \mathrm{BPA}\right)$, group-5 $\left(\mathrm{T}_{3}+\right.$ $10^{-6} \mathrm{M}$ TBBPA), group-7 ( $\mathrm{T}_{3}+10^{-6} \mathrm{M}$ TCBPA) or group $-9\left(\mathrm{~T}_{3}+10^{-6} \mathrm{M}\right.$ TMBPA) tadpoles. Nor were such changes observed in group-2 $\left(10^{-6} \mathrm{M}\right.$ BPA $)$, 


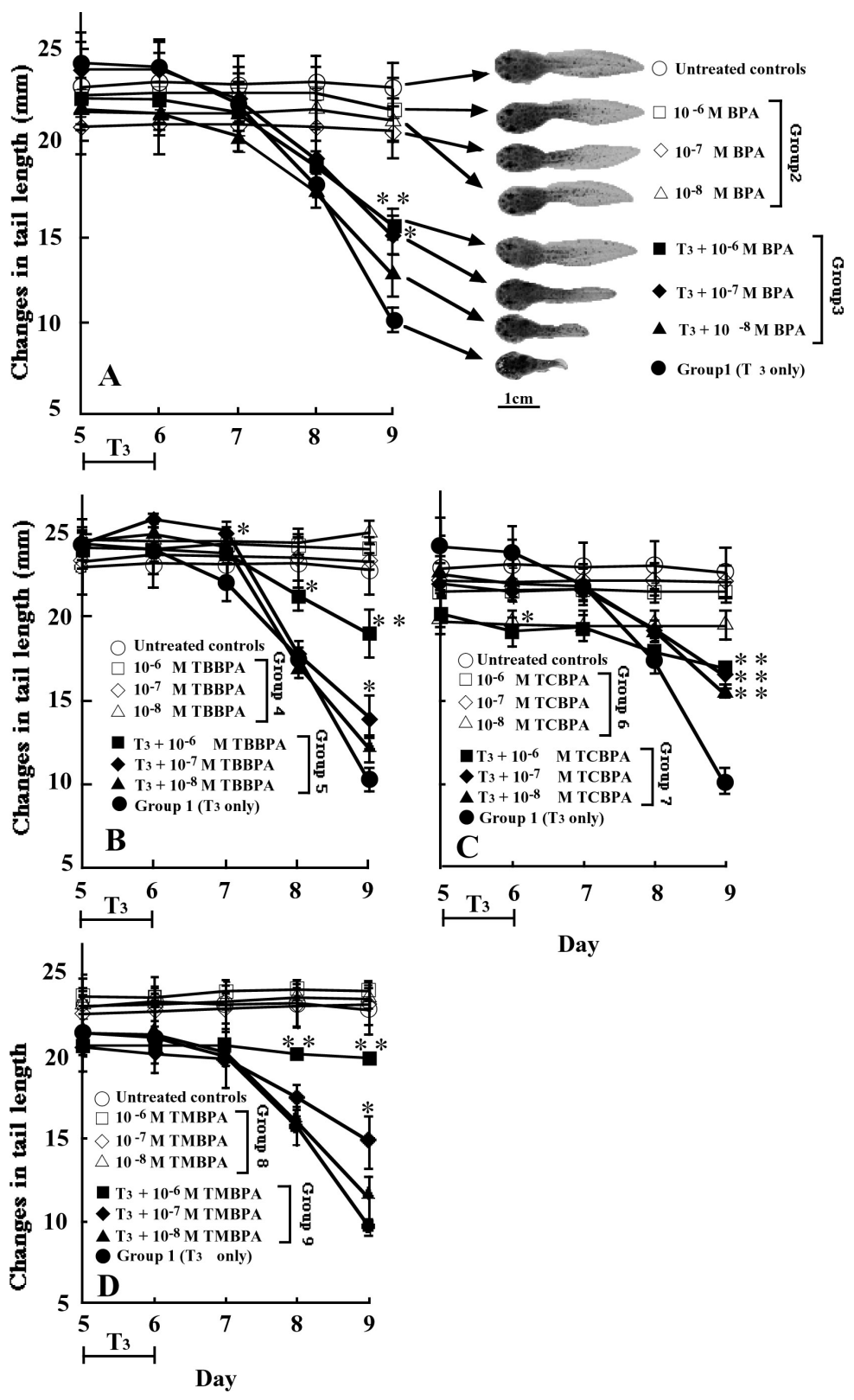

Fig. 2. Effect of BPA, TBBPA, TCBPA and TMBPA on Tail Shortening in $\mathrm{T}_{3}$-Treated and Untreated $R$. rugosa Tadpoles

*Significantly greater $(p<0.05)$ than corresponding values for group-1 tadpoles. **Significantly greater $(p<0.01)$ than corresponding values for group-1 tadpoles.

group-4 $\left(10^{-6} \mathrm{M}\right.$ TBBPA), group-6 $\left(10^{-6} \mathrm{M}\right.$ TCBPA $)$ or group-8 $\left(10^{-6} \mathrm{M}\right.$ TMBPA $)$ tadpoles.

\section{Effects of BPA and Related Compounds on Spon- taneous Metamorphosis, Tail Shortening and Hindlimb Elongation}

S. tropicalis is becoming increasingly popular for use in developmental and genetic studies because it possesses a diploid genome ${ }^{35-37)}$ and has a relatively short generation time of approximately 4 months for males and 5 months for females. In the species $X$. laevis endogenous plasma TH values are low at prometamorphic stages $56-57,{ }^{38)}$ but increase markedly at midclimax stages $61-62^{38)}$ at the beginning of spontaneous rapid tadpole tail shortening. ${ }^{39)}$ Endogenous plasma TH values are not available for $S$. tropicalis, but we assume they operate in a manner similar to that seen in X. laevis. Two stage $57 \mathrm{~S}$. tropicalis tadpoles were kept in trays containing $200 \mathrm{ml}$ of $10^{-6} \mathrm{M}$ solutions of BPA, TBBPA, TCBPA or TMBPA, or a $1 \mathrm{mM}$ solution of the methimazole $\mathrm{TH}$ synthesis inhibitor. Tadpoles raised in Cl-free 


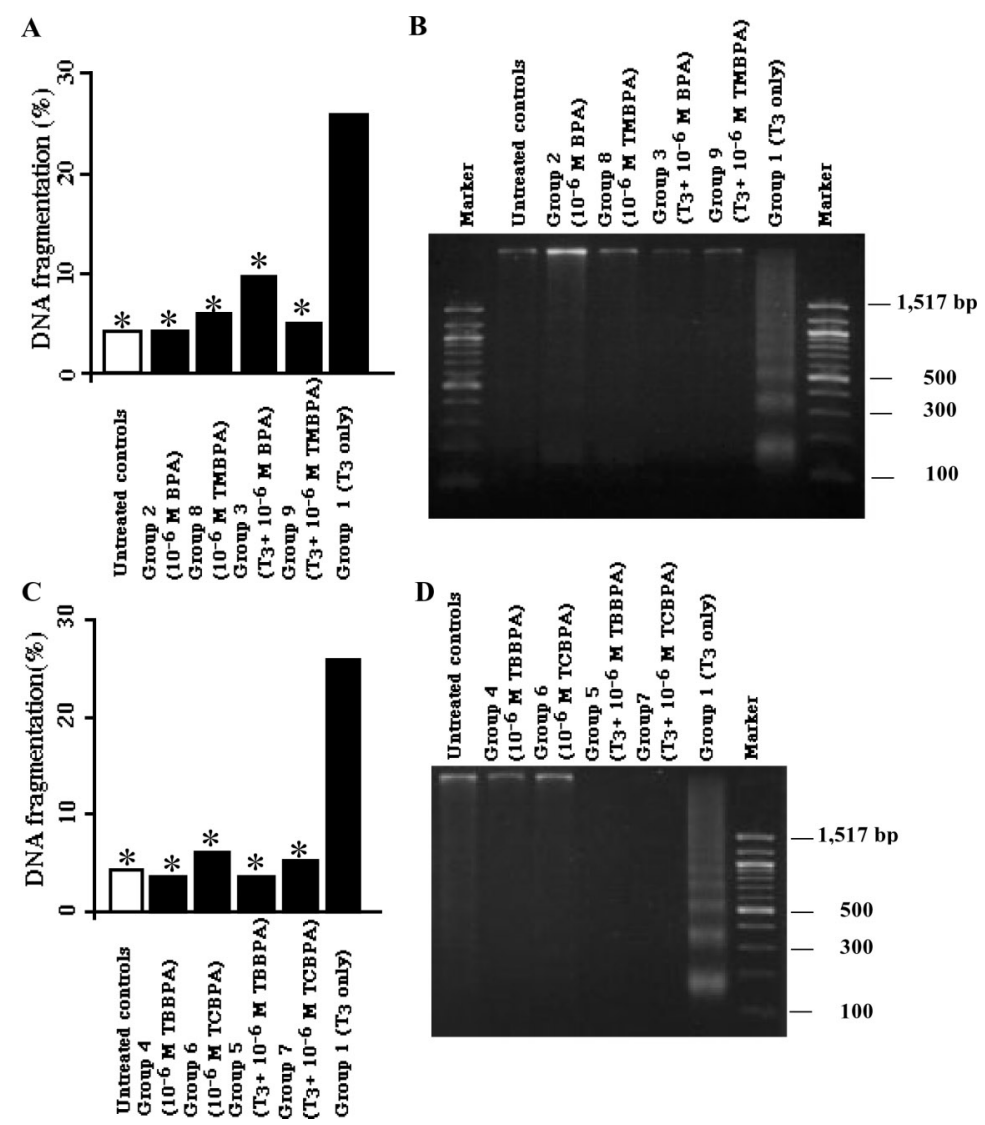

Fig. 3. Effect of BPA, TBBPA, TCBPA and TMBPA on DNA Fragmentation and Ladder Formation in Tails of $\mathrm{T}_{3}$-Treated and Untreated $R$. rugosa Tadpoles

$(\mathrm{A}, \mathrm{C})$ DNA fragmentation; (B, D) Ladder formation. Each experiment was carried out using three tadpoles. Values given represent the mean value of three repetitions. *Significantly less $(p<0.01)$ than group-1 value.
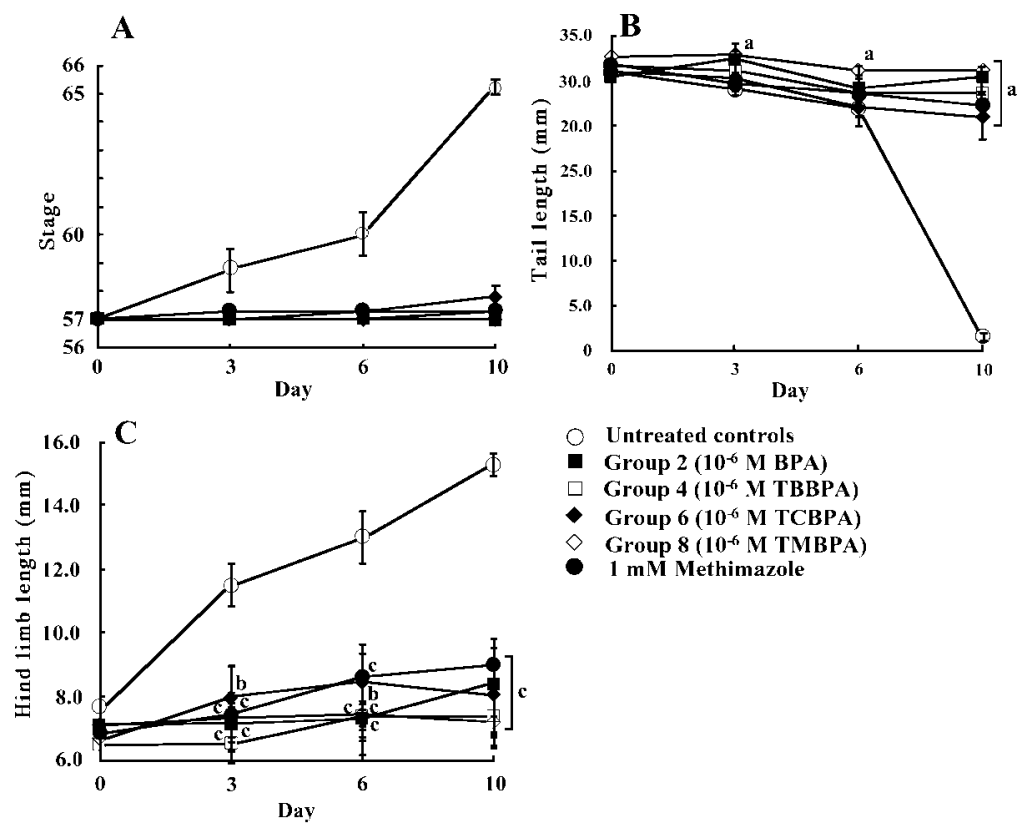

Untreated controls

- Group $2\left(10^{-6} \mathrm{M}\right.$ BPA $)$

$\square$ Group $4\left(10^{-6}\right.$ M TBBPA $)$

- Group $6\left(10^{-6} \mathrm{M}\right.$ TCBPA $)$

$\diamond$ Group $8\left(10^{-6} \mathrm{M}\right.$ TMBPA $)$

- $1 \mathrm{mM}$ Methimazole

Fig. 4. Suppression of Spontaneous Metamorphosis (A), Tadpole Tail Shortening (B) and Hindlimb Elongation (C) by BPA, TBBPA, TCBPA, TMBPA and Methimazole in S. tropicalis

${ }^{a}$ Significantly greater $(p<0.01)$ than corresponding values for untreated tadpoles. ${ }^{\mathrm{b}}$ Significantly less $(p<0.05)$ than corresponding values for untreated tadpoles. 'Significantly less $(p<0.01)$ than corresponding values for untreated tadpoles. 

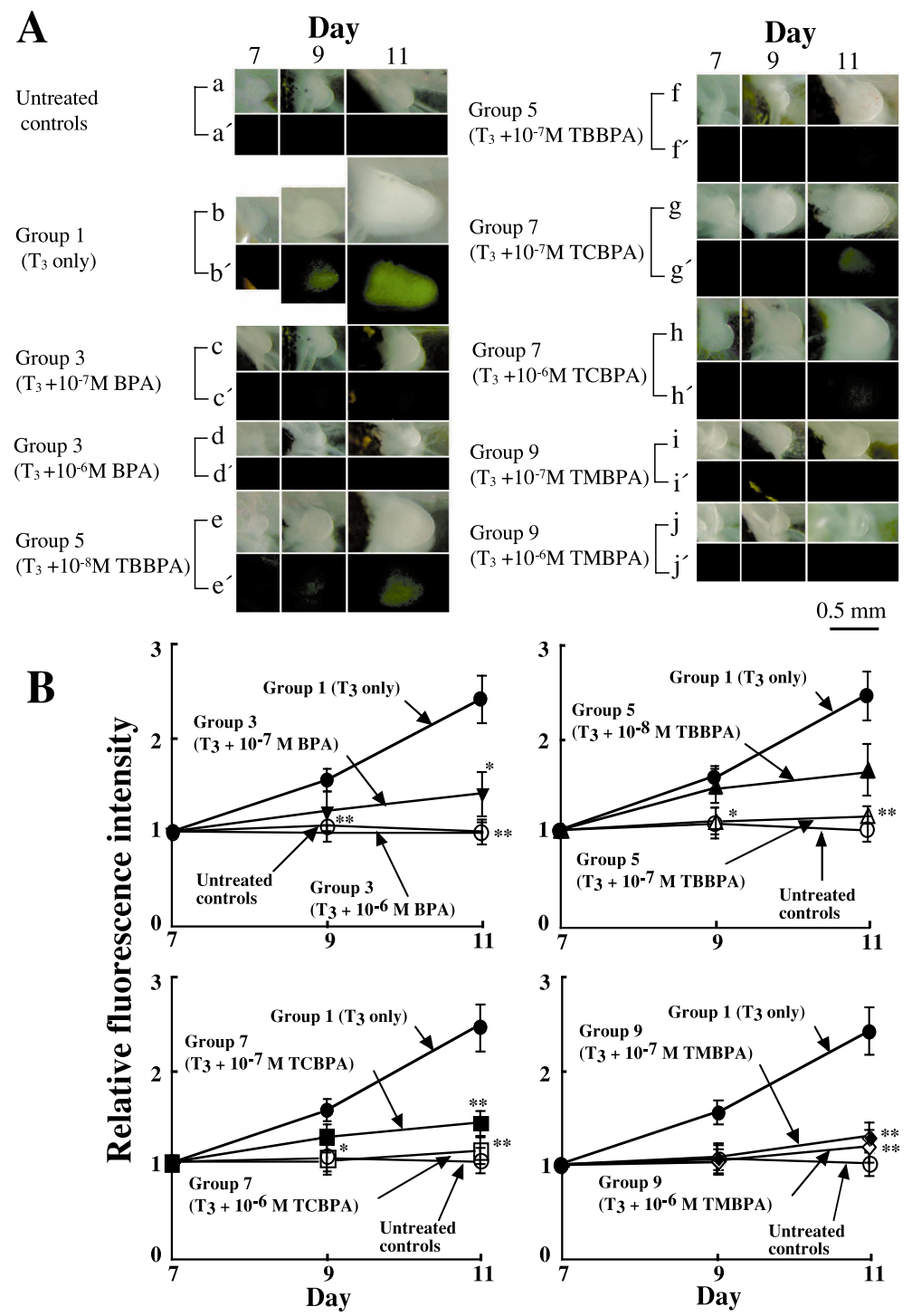

Fig. 5. EGFP Activity in Hindlimbs of $\mathrm{T}_{3}$-Treated Transgenic $X$. laevis Tadpoles and Suppression by BPA, TBBPA, TCBPA and TMBPA (A) Dorsal views of hindlimbs in reflected light $(\mathrm{a}-\mathrm{j})$ and EGFP fluorescence (a'-j'). (B) EGFP activity. *Significantly less $(p<0.05)$ than corresponding values for group-1 tadpoles. **Significantly less $(p<0.01)$ than corresponding values for group-1 tadpoles.

water served as untreated controls. The experiments were repeated three times. Figure 4 shows that BPA and related compounds suppressed spontaneous metamorphosis, tadpole tail shortening and hindlimb elongation, as did $1 \mathrm{mM}$ methimazole.

\section{Effects of BPA and Related Compounds on TR- Mediated Gene Transcription}

The ability of BPA and related compounds to prevent TR-mediated gene expression was examined using $\mathrm{F}_{2}$ transgenic $X$. laevis tadpoles expressing EGFP driven by TR $\beta$ A 1 promoter region containing TRE. EGFP fluorescence in the hindlimbs rose during treatment with $\mathrm{T}_{3}$ (Fig. 5A), and activity increased about $250 \%$ over the original level by day 11
(Fig. 5B). The change in EGFP activity in $\mathrm{T}_{3}$-treated tadpoles was significantly suppressed in the presence of BPA, TBBPA, TCBPA or TMBPA.

\section{DISCUSSION}

Although several classes of environmental contaminants (ECs) adversely disrupt thyroid function, ${ }^{40,41)}$ the reasons for this interference remain unclear. ECs have been found to disrupt thyroid gland function and regulation, TH metabolism, and TH transport binding proteins. A number of chemicals are thought to bind to the $\mathrm{T}_{4}$-binding protein transthyretin (TTR), which displaces $\mathrm{T}_{4}$, leading to 
an increase in the clearance of $\mathrm{T}_{4}$ and a decrease in serum $\mathrm{T}_{4}$ concentrations. ${ }^{42)}$ TCBPA is reported to bind to TTR with lesser affinity than TBBPA. ${ }^{43}$

A few in vitro studies have been reported on the detrimental effects of BPA and related compounds on TH action. BPA inhibits $\mathrm{T}_{3}$-induced differentiation of mouse oligodendrocytes. ${ }^{44)}$ In human embryonic kidney cells and hepatoblastoma cells, Moriyama et al. ${ }^{5}$ found that BPA inhibits $\mathrm{T}_{3}$ binding to TR and recruited nuclear receptor corepressors (N-CoRs) resulting in transcriptional suppression. TBBPA, TCBPA and TMBPA markedly inhibited $\mathrm{T}_{3}$ binding to TR using nuclear fraction of $\mathrm{GH} 3$ cells. ${ }^{11,12)}$ Recently an in vivo investigation using rats showed that BPA acts as a TH antagonist on the $\beta$ TR and inhibits negative feedback, leading to elevated $\mathrm{T}_{4}$ level. ${ }^{45}$ ) Iwamuro et al.${ }^{6}$ ) reported that BPA suppresses spontaneous and $\mathrm{T}_{3}$-induced metamorphosis in $X$. laevis tadpoles, blocking TR $\beta$ gene expression.

In a recent investigation using reporter assay in a Chinese hamster ovary cell line (CHO-K1) transfected with $\mathrm{TH} \alpha 1$ or $\beta 1$, Kitamura et al. ${ }^{12)}$ reported that both TBBPA and TCBPA exhibit significant antithyroid hormone effects on $\mathrm{T}_{3}$ activity. Kitamura et $a l .{ }^{12)}$ also reported that TBBPA suppresses $R$. rugosa tadpole tails undergoing regression during $\mathrm{T}_{3}$ enhancement. In the present study, BPA, TBBPA, TCBPA and TMBPA were found to inhibit the regression of $R$. rugosa tadpole tails induced by exogenously added $\mathrm{T}_{3}$, as well as spontaneous $S$. tropicalis metamorphosis by endogenous circulating $\mathrm{TH}$ in a dose-dependent manner, suggesting that BPA and related compounds act as TH antagonists. TMBPA showed the highest activity, followed by TCBPA, TBBPA and BPA. Moreover, we found that exposure of $\mathrm{T}_{3}$ to transgenic Xenopus tadpoles overexpressing TRE expression induced a marked expression of EGFP gene, while the addition of BPA, TBBPA, TCBBA or TMBPA blocked this EGFP expression in a dose-dependent manner. It seems likely that by binding to TR, these chemicals compete with $\mathrm{T}_{3}$, resulting in suppression of TR-mediated gene transcription. Such transgenic lines overexpressing $\mathrm{TH}$ enhanced gene sets have proven to be a useful bioassay for detecting chemical compounds possessing $\mathrm{TH}$ antagonism or agonism.

Tadpole tail shortening through muscle cell apoptosis is one of the most spectacular events in anuran metamorphosis. We reported that an increase in thyroid hormone $\left(\mathrm{T}_{4}\right)$ enhances nitric oxide (NO) generation, thereby strongly inhibiting catalase ac- tivity, resulting in an increase in hydrogen peroxide $\left(\mathrm{H}_{2} \mathrm{O}_{2}\right)$, and that the oxidative stress elicited by excess $\mathrm{H}_{2} \mathrm{O}_{2}$ might activate cysteine-dependent aspartate-directed protease-3 (caspase-3), which induces DNA fragmentation, leading to apoptosis. ${ }^{25,26,46)} \mathrm{We}$ also reported that mitochondrial membrane permeability transition (MPT) is important in the mechanism of $\mathrm{T}_{3}$-induced shortening of tadpole tails, and that tail muscle apoptosis is regulated by Bax gene in a cyclosporin A (CsA) sensitive mechanism..$^{27,47)}$ At present, we are conducting investigations aimed at clarifying the effects of BPA and related compounds on NO generation and MPT in tail regression.

In the present study, we found that exposure of transgenic tadpoles to $\mathrm{T}_{3}$ induced the expression of EGFP gene, while exposure of $\mathrm{T}_{3}$ plus BPA, TBBPA, TCBPA or TMBPA suppressed EGFP expression, suggesting that BPA and related substances downregulate the gene expression mediated by TR. Transgenic lines exploiting TR-TRE are useful for investigating the effects of endocrine disrupting chemicals on TR-mediated gene transcription.

Acknowledgements This work was supported by Grant-in-Aid for Scientific Research on Priority Area (13027256) from the Japanese Ministry of Education, Science, Sports and Culture, and Grant-in-Aid for Scientific Research (C13672343) from Japan Society for the Promotion of Science.

\section{REFERENCES}

1) Colborn, T., vom Saal, F. S. and Soto, A. M. (1993) Developmental effects of endocrine-disrupting chemicals in wildlife and humans. Environ. Health Perspect., 101, 378-384.

2) Davis, D. L., Bradlow, H. L., Wolff, M., Woodruff, T., Hoel, D. G. and Anton-Culver, H. (1993) Medical hypothesis: xenoestrogens as preventable causes of breast cancer. Environ. Health Perspect., 101, 372-377.

3) Kavlock, R. J., Daston, G. P., DeRosa, C., FennerCrisp, P., Gray, L. E., Kaattari, S., Lucier, G., Luster, M., Mac, M. J., Maczka, C., Miller, R., Moore, J., Rolland, R., Scott, G., Sheehan, D. M., Sinks, T. and Tilson, H. A. (1996) Research needs for the risk assessment of health and environmental effects of endocrine disruptors: a report of the U.S. EPA-sponsored workshop. Environ. Health Perspect., 104 (suppl. 4), 715-740.

4) Toppari, J., Larsen, J. C., Christiansen, P., 
Giwercman, A., Grandjean, P., Guillette, L. J., Jr., Jegou, B., Jensen, T. K., Jouannet, P., Keiding, N., Leffers, H., McLachlan, J. A., Meyer, O., Muller, J., Rajpert-De Meyts, E., Scheike, T., Sharpe, R., Sumpter, J. and Skakkebaek, N. E. (1996) Male reproductive health and environmental xenoestrogens. Environ. Health Perspect., 104(suppl. 4) 741-803.

5) Moriyama, K., Tagami, T., Akamizu, T., Usui, T., Saijo, M., Kanamoto, N., Hataya, Y., Shimatsu, A., Kuzuya, H. and Nakao, K. (2002) Thyroid hormone action is disrupted by bisphenol A as an antagonist. J. Clin. Endocrinol. Metab., 87, 5185-5190.

6) Iwamuro, S., Sakakibara, M., Terao, M., Ozawa, A., Kurobe, C., Shigeura, T., Kato, M. and Kikuyama, S. (2003) Teratogenic and anti-metamorphic effects of bisphenol A on embryonic and larval Xenopus laevis. Gen. Comp. Endocrinol., 133, 189-198.

7) Markey, C. M., Rubin, B. S., Soto, A. M. and Sonnenschein, C. (2002) Endocrine disruptors: from Wingspread to environmental developmental biology. J. Steroid Biochem. Mol. Biol., 83, 235-244.

8) Körner, W., Hanf, V., Schuller, W., Bartsch, H., Zwirner, M. and Hagenmaier, H. W. (1998) Validation and application of a rapid in vitro assay for assessing the estrogenic potency of halogenated phenolic chemicals. Chemosphere, 37, 2395-2407.

9) Meerts, I. A. T. M., Letcher, R. J., Hoving, S., Marsh, G., Bergman, A. A., Lemmen, J. G., van der Burg, B. and Brouwer, A. (2001) In vitro estrogenicity of polybrominated diphenyl ethers, hydroxylated PDBEs, and polybrominated bisphenol A compounds. Environ. Health Perspect., 109, 399-407.

10) Samuelsen, M., Olsen, C., Holme, J. A., MeussenElholm, E., Bergmann, A. and Hongslo, J. K. (2001) Estrogen-like properties of brominated analogs of bisphenol A in the MCF-7 human breast cancer cell line. Cell Biol. Toxicol., 17, 139-151.

11) Kitamura, S., Jinno, N., Ohta, S., Kuroki, H. and Fujimoto, N. (2002) Thyroid hormonal activity of the flame retardants tetrabromobisphenol A and tetrachlorobisphenol A. Biochem. Biophys. Res. Commun., 293, 554-559.

12) Kitamura, S., Kato, T., Iida, M., Jinno, N., Suzuki, T., Ohta, S., Fujimoto, N., Hanada, H., Kashiwagi, K. and Kashiwagi, A. (2005) Anti-thyroid hormonal activity of tetrabromobisphenol A, a flame retardant, and related compounds: Affinity to the mammalian thyroid hormone receptor, and effect on tadpole metamorphosis. Life Sci., 76, 1589-1601.

13) Jagnytsch, O., Opitz, R., Lutz, I. and Kloas, W. (2006) Effects of tetrabromobisphenol A on larval development and thyroid hormone-regulated biomarkers of the amphibian Xenopus laevis. Environ. Res., http://www.elsevier.com/locate/ envres, in press.

14) Fukazawa, H., Hoshino, K., Shiozawa, T., Matsushita, H. and Terao, Y. (2001) Identification and quantification of chlorinated bisphenol $\mathrm{A}$ in wastewater from wastepaper recycling plants. Chemosphere, 44, 973-979.

15) Dodd, M. H. and Dodd, L. M. (1976) The biology of metamorphosis. In Physiology of the Amphibia. vol. 3 (Lofts, B., Ed.), Academic Press, New York, San Francisco, London, pp. 467-599.

16) Brown, D. D., Wang, Z., Furlow, J. D., Kanamori, A., Schwartzman, R. A., Remo, B. F. and Pinder, A. (1996) The thyroid hormone-induced tail resorption program during Xenopus laevis metamorphosis. Proc. Natl. Acad. Sci. U.S.A., 93, 1924-1929.

17) Denver, R. J. (1998) The molecular basis of thyroid hormone-dependent central nervous system remodeling during amphibian metamorphosis. Comp. Biochem. Physiol. C, 119, 219-228.

18) Shi, Y.-B. (2000) Amphibian Metamorphosis, WileyLiss, New York, Chichester, Weinheim, Brisbane, Singapore, Toronto.

19) Inoue, M., Sato, E. F., Nishikawa, M., Hiramoto, K., Kashiwagi, A. and Utsumi, K. (2004) Free radical theory of mitochondria-dependent apoptosis and metamorphosis. Redox Rep., 9, 237-247.

20) Shi, Y.-B. (1994) Molecular biology of amphibian metamorphosis. A new approach to an old problem. TEM, 5, 14-20.

21) Kerr, J. F. R., Harmon, B. and Searle, J. (1974) An electronmicroscope study of cell deletion in the anuran tadpole tail during spontaneous metamorphosis with special reference to apoptosis of striated muscle fibers. J. Cell Sci., 14, 571-585.

22) Kashiwagi, A., Hanada, H., Yabuki, M. and Utsumi, K. (2000) Reactive oxygen species and the mechanism for tail apoptosis in Rana rugosa and Rana japonica. Recent Res. Devel. Comparative Biochem. Physiol., 1, 51-66.

23) Thornberry, N. A. and Lazebnik, Y. (1998) Caspases: enemies within. Science, 281, 1312-1316.

24) Robinson, H. (1972) An electrophoretic and biochemical analysis of acid phosphatase in the tail of Xenopus laevis during development and metamorphosis. J. Exp. Zool., 180, 127-140.

25) Kashiwagi, A. (1995) Peroxisomal enzyme activity changes in the tail of anuran tadpoles during metamorphosis. Comp. Biochem. Physiol. B, 111, 483489.

26) Kashiwagi, A., Hanada, H., Yabuki, M., Kanno, T., Ishisaka, R., Sasaki, J., Inoue, M. and Utsumi, K. (1999) Thyroxine enhancement and the role of reactive oxygen species in tadpole tail apoptosis. Free Radic. Biol. Med., 26, 1001-1009. 
27) Hanada, H., Katsu, K., Kanno, T., Sato, E. F., Kashiwagi, A., Sasaki, J., Inoue, M. and Utsumi, K. (2003) Cyclosporin A inhibits thyroid hormoneinduced shortening of the tadpole tail through membrane permeability transition. Comp. Biochem. Physiol. B, 135, 473-483.

28) Taylor, A. C. and Kollros, J. J. (1946) Stages in the normal development of Rana pipiens larvae. Anat. Rec., 94, 7-24.

29) Nieuwkoop, P. D. and Faber, J. (1956) Normal Tables of Xenopus laevis (Daudin), North-Holland, Amsterdam.

30) Burton, K. (1956) A study of the conditions and mechanisms of the diphenylamine reaction for the colorimetric estimation of deoxyribonucleic acid. Biochem. J., 62, 315-323.

31) Miller, S. A., Dykes, D. D. and Polesky, H. F. (1988) A simple salting out procedure for extracting DNA from human nucleated cells. Nucleic Acids Res., 16, 1215-1218.

32) Sambrook, J., Fritsch, E. F. and Maniatis, T. (1987) Gel electrophoresis of DNA. In Molecular Cloning: A Laboratory Manual, 2nd ed. Vol. 6 (Ford, N., Nolan, C. and Ferguson, M., Eds.), Cold Spring Harbor, New York, pp. 1-62.

33) Kroll, K. L. and Amaya, E. (1996) Transgenic Xenopus embryos from sperm nuclear transplantations reveal FGF signaling requirements during gastrulation. Development, 122, 3173-3183.

34) Oofusa, K., Tooi, O., Kashiwagi, A., Kashiwagi, K., Kondo, Y., Watanabe, Y., Sawada, T., Fujikawa, K. and Yoshizato, K. (2001) Expression of thyroid hormone receptor $\beta \mathrm{A}$ gene assayed by transgenic Xenopus laevis carrying its promoter sequences. Mol. Cell. Endocrinol., 181, 97-110.

35) Tymowska, J. (1973) Karyotype analysis of Xenopus tropicalis Gray, Pipidae. Cytogenetic. Cell Genet., 12, 297-304.

36) Tymowska, J. (1991) Polyploidy and cytogenetic variation in frogs of the genus Xenopus. In Amphibian Cytogenetics and Evolution (Green, D. M. and Sessions, S. K., Eds.), Academic Press, San Diego, New York, Boston, London, Sydney, Tokyo, Toronto, pp. 259-297.

37) Tymowska, J. and Fischberg, M. (1973) Chromosome complements of the genus Xenopus. Chromosoma (Berl.), 44, 335-342.

38) Leloup, J. and Buscaglia, M. (1977) La triiodothyronine: hormone de la métamorphose des amphibiens.
C. R. Acad. Sci., 284, 2261-2263.

39) Atkinson, B. G. (1981) Biological basis of tissue regression and synthesis. In Metamorphosis: A Problem in Developmental Biology, 2nd ed. (Gilbert, L. I. and Frieden, E., Eds.), Plenum Press, New York, pp. 397-444.

40) Brouwer, A., Morse, D. C., Lans, M. C., Schuur, A. G., Murk, A. J., Klasson-Wehler, E., Bergman, A. and Visser, T. J. (1998) Interactions of persistent environmental organohalogens with the thyroid hormone system: mechanisms and possible consequences for animal and human health. Toxicol. Ind. Health, 14, 59-84.

41) Brucker-Davis, F. (1998) Effects of environmental synthetic chemicals on thyroid function. Thyroid, 8, 827-856.

42) Darnerud, P. O., Morse, D., Klasson-Wehler, E. and Brouwer, A. (1996) Binding of a 3,3',4,4'tetrachlorobiphenyl (CB-77) metabolite to fetal transthyretin and effects on fetal thyroid hormone levels in mice. Toxicology, 106, 105-114.

43) Meerts, I. A. T. M., van Zanden, J. J., Luijks, E. A. C., van Leeuwen-Bol, I., Marsh, G., Jakobsson, E., Bergman, Å. and Brouwer, A. (2000) Potent competitive interactions of some brominated flame retardants and related compounds with human transthyretin in vitro. Toxicol. Sci., 56, 95-104.

44) Seiwa, C., Nakahara, J., Komiyama, T., Katsu, Y., Iguchi, T. and Asou, H. (2004) Bisphenol A exerts thyroid-hormone-like effects on mouse oligodendrocyte precursor cells. Neuroendocrinology, 80, 2130.

45) Zoeller, R. T., Bansal, R. and Parris, C. (2005) Bisphenol-A, an environmental contaminant that acts as a thyroid hormone receptor antagonist in vitro, increases serum thyroxine, and alters RC3/ neurogranin expression in the developing rat brain. Endocrinology, 146, 607-612.

46) Hanada, H., Kashiwagi, A., Takehara, Y., Kanno, T., Yabuki, M., Sasaki, J., Inoue, M. and Utsumi, K. (1997) Do reactive oxygen species underlie the mechanism of apoptosis in the tadpole tail? Free Radic. Biol. Med., 23, 294-301.

47) Kashiwagi, A., Kanno, T., Arita, K., Ishisaka, R., Utsumi, T. and Utsumi, K. (2001) Suppression of $\mathrm{T}_{3}$ - and fatty acid-induced membrane permeability transition by L-carnitine. Comp. Biochem. Physiol. $B, \mathbf{1 3 0}, 411-418$. 